\title{
Grey water pollutant loads in residential colony and its economic management
}

\author{
Anil Kumar Shankhwar*, Sudipta Ramola, Tripti Mishra and Rajeev Kumar Srivastava
}

\begin{abstract}
The present paper deals with the organic loadings of grey water with its average and maximum flow rate on an hourly and daily basis generated from the residential colony of G.B. Pant University of Agriculture and Technology, Pantnagar, India. For reliable quantification, the study was conducted at the interval of $1 \mathrm{~h}$ for eight consecutive days in each season during the year 2012 to 2013. Following parameters viz biochemical oxygen demand (BOD), chemical oxygen demand (COD), nitrogen, phosphorus, and potassium analyses were used to calculate grey water pollutant load. The observed annual average organic pollutant loading in terms of BOD was found to be 29.44 $\mathrm{kg} /$ day with maximum load in the summer season. However, this organic loading at maximum flow rate basis (in peak hours) was varied seasonally from $55.3,52.0$, and $83.3 \mathrm{~kg} /$ day, respectively, during the monsoon, winter, and summer seasons. The grey water discharge flow rate reveals the need of a treatment system compatible with fluctuating pollutant loads. The bioefficacy of phytoremediation-based technology was assessed and found to be maximum in the summer season. Hence, it is found to be the best suited green alternative for combating the fluctuating pollutant load.
\end{abstract}

Keywords: Bioefficacy; Biochemical oxygen demand; Grey water; Economic management; Residential colony; Pollutant loading

\section{Background}

These days' technology involved in wastewater treatment uses innovative, efficient, and advanced methods. However, these need to be economically viable, especially in the rural part of India in order to support wastewater treatment and reuses. Freshwater scarcity is a worldwide challenge for sustainable development. Human interference, inadequate freshwater supply, and inappropriate management leads to more pollutant load of water. Thus, the reuse of municipal wastewater is becoming an important issue with increasing water demand for human consumption and agricultural production (Shankhwar and Srivastava 2012). Vis-à-vis, the green technology based on the short rotation-plantation fertigation system worked like a panacea. For this purpose, the quantification of generated wastewater and its pollutant load is a prerequisite asset. Domestic wastewater is often categorized into black water (from toilets) and grey water (from bathrooms and kitchen). The drivers of wastewater generation from the nonpoint sources of pollution are multiple, and consequently, grey

* Correspondence: oxeegen@gmail.com

Department of Environmental Science, G.B. Pant University of Agriculture and Technology, Pantnagar, U.S. Nagar, Uttarakhand 263145, India water characteristics and discharge flow rate also varied greatly and are tedious to predict (Piao et al. 2010; Koutsouris et al. 2010; Wagener et al. 2010; Bring and Destouni 2011; Destouni et al. 2013). Besides this, due to population explosion, the grey water generation escalates in a multifold ratio. The unequal generation of wastewater with a continuous variation in time series from hour to hour, day to day, and month to month (Henze et al. 2000) creates a major hurdle in the preparation of a blueprint for any wastewater treatment strategy. Therefore, in the current scenario, there is an emergent and urgent need for accurate information about generated wastewater with its hourly, daily, and seasonal variation as a major prerequisite prior to designing and establishing any wastewater treatment plant and reuse plan. This calls for a time-to-time update about the flow rate and pollutant load of generated wastewater. Grey water represents $70 \%$ of total domestic wastewater which has relatively fewer loads of pollutants in comparison to black water and negligible amounts of heavy metals and pathogens (Pandey et al. 2014). Thus, grey water enables optimum concentration of pollutants to harness as nutrients and holds a great potential of recycle and reuse as well. 
Keeping in view all these factors, the main goal of present research was exclusively to investigate the grey water discharge pattern and organic pollutant load generated from hostels and residential colonies of a university campus. Mitigation of grey water pollution by harnessing the available nutrients through green management technology like the Short Rotation Intensive Cultural Plantation System (SRICPS) can be further introduced for sustainable use of wastewater as a resource.

\section{Methods}

\section{Project site description}

Geographically, the study location lies about $30 \mathrm{~km}$ southwards of the Shivalik range of the Himalayan foothill at $29^{\circ} 1^{\prime} 55^{\prime \prime} \mathrm{N}$ latitude, $79^{\circ} 28^{\prime} 25^{\prime \prime}$ E longitude and at an altitude of $243.8 \mathrm{~m}$ above the MSL. The site was selected in the residential area of G.B. Pant University of Agriculture and Technology, Pantnagar, Uttarakhand, India for grey water assessment. The area has humid, subtropical climatic conditions with 1,608 mm mean annual rainfall.

\section{Selection of location for grey water quantification}

The location was selected in the main drainage channel from the residential colonies of Shastri Enclave and Shivalik Enclave, etc. near Shri Maha Kaleshwar Nath Temple, Pantnagar. The grey water samples were collected from the drain before it joins the Barur River which is around $200 \mathrm{~m}$ away. The analysis of discharged grey water for pollutant load and flow rate estimation was intentionally done at the same location for more accuracy of results.

\section{Grey water quality analyses}

Grey water composite samples were analyzed in triplicates with the flow rate measurement and sampling for other analyses also done simultaneously. The selected water quality parameters were $\mathrm{pH}$, biochemical oxygen demand (BOD), chemical oxygen demand (COD), total solids (TS), total suspended solids (TSS), total dissolved solids (TDS), total carbon (TC), total nitrogen (TN), total phosphorus (TP), and total potassium (TK). For the qualitative analysis, one composite sample was taken into triplicates for representing each individual day characteristics of grey water. All of the mentioned water quality parameters except total carbon and total nitrogen were analyzed as per the standard method (APHA 1998). TC and TN were analyzed through total organic carbon (TOC) analyzer instrument.

\section{Grey water flow measurement}

The season-wise grey water flow rate was measured at interval of $1 \mathrm{~h}$ for eight consecutive days in each season from $4 \mathrm{AM}$ to $10 \mathrm{PM}$. The measurement was done by using data collected with the help of V-notch to measure the discharges in the 0 to $0.15 \mathrm{~m}^{3} / \mathrm{s}$ range as per measurement details given by NPDES (1977). The calibration (Equation 1) was considered for seasonal quantification of the grey water flow rate. The formula is known as the Cone formula and was applied for accurate water flow rate quantification because it is more reliable than other weir methods due to its simplicity. Furthermore, invariably, the equation of best fit is derived in following form of

$$
Q={ }_{a} H^{b}
$$

Where $Q$ is the flow of the grey water, and $H$ is the head over weir. The coefficients $a$ and $b$ are experimentally determined by regression coefficients and variable for water flow range as per NPDES (1977).

$$
Q={ }_{1.34} H^{2.48}
$$

The values of $a$ and $b$ were taken as 1.34 and 2.48, respectively, and defined on the basis of observations for overhead height $H$, in the range of 0.06 to $0.13 \mathrm{~m}$, respectively (Robert 1986).

\section{Grey water in organic loading}

Organic pollutant loading of grey water discharged into drain depends on its flow rate and pollutant strength. Therefore, variations of grey water organic pollutant load were calculated continuously hourly, daily, seasonal, and annual basis to investigate the accurate grey water pollutant loading at different times for proper treatment design and water pollutant mitigation. The organic pollutant loading was calculated as per formula given by EPA (1997).

$$
\mathrm{OL}(\mathrm{kg} / \text { day })=\frac{Q\left(\mathrm{~m}^{3} / \text { day }\right) \times \mathrm{BOD}_{5}(\mathrm{mg} / \mathrm{l})}{1,000}
$$

Where OL is organic load ( $\mathrm{kg} /$ day), $Q$ is daily flow $\left(\mathrm{m}^{3} /\right.$ day $)$, BOD $_{5}$ is BOD taken at 5 days $(\mathrm{mg} / \mathrm{l})$, and 1,000 is used to convert in kilogram per day from gram per day.

\section{Green management technology for grey water recycling}

The green management of grey water pollutant load can be done by harnessing the phytoremediation ability of short rotation trees. Crops require a high quantity of nutrients to harvest their potential yields. The system overall is input intensive (Jeet et al. 2014). This ability provides the new avenue of biomass production even at marginal wastelands and bunds. Furthermore, it facilitates the more resilient ecosystem on economic basis. Hence, the SRICPS was assessed for the treatment of grey wastewater. A Eucalyptus hybrid (clone K-413) was fertigated with grey domestic wastewater for biomass 
production trial under SRICPS. For the dual purpose of biomass production and phytoremediation, the saplings of Eucalyptus hybrid (clone K-413) were transplanted in November 2010 in an experimental trial field of University farmland. The Eucalyptus hybrid (clone K-413) is a hybrid product selected by virtue of its wide adaptability of climatic conditions, phytoremediation potential, and timber wood yield as well as resistance against various insects, pests, and diseases. In the trial, the plantation was intensively fertigated with the grey water in serpentine and channel irrigation regimes. The bioefficacy of SRICPS to remediate grey water was assessed with the tree biomass productivity as well (Shankhwar and Srivastava 2014).

\section{Results and discussion}

The quantification of grey water generation was calculated in terms of average values of hourly, monthly, daily, and annual basis. The average value of observed grey water generation was recorded to be 86.76 (l/person/day (lpd)) liters per capita per day. However, this value was around $64 \%$ of that recommended by the Indian Standards (IS: 1172-1963), i.e., water consumption requirement of $135 \mathrm{lpd}$. Generally, 75\% to $85 \%$ of wastewater discharge is considered sewage water which includes black and grey water, but in the present case, the black water is allowed to go into the septic tanks of each house, hostel, and college because the University campus has no sewage treatment facility.

The grey water quality was found to have a clear cut seasonal variation. The annual data of grey water quality was found to significantly lower the degree of pollutants when compared to the permissible limit of discharge. The grey water organic load on the average and maximum low rate basis was calculated in different seasons of the year. The maximum loading due to average and maximum flow rate was recorded to be significantly higher in the summer season, i.e., 33.31 and $83.34 \mathrm{~kg} /$ day, respectively. However, in the winter season, the minimum loading was found to be 24.05 and $52.0 \mathrm{~kg} /$ day, respectively, due to the higher organic loading; in the summer season, the maximum loading was due to more consumption of water in the household. Hence, it is required that more efficient treatment is needed during this period (Table 1).

The average hourly flow rate $\left(\mathrm{m}^{3} / \mathrm{hr}\right)$ of domestic wastewater (grey water) discharged into the drain during different seasons has been depicted in Figure 1. The results obtained from the figure revealed that the maximum flow rate of grey water was between 9 to $10 \mathrm{AM}$. Whereas, the flow rate of grey water started to increase from 3 to $5 \mathrm{~m}^{3} / \mathrm{hr}$ at 5:00 AM to maximum, i.e., 35 to $38 \mathrm{~m}^{3} / \mathrm{hr}$ at $10 \mathrm{AM}$ in all seasons. After this, a sharp decrease in flow rate was noticed at $11 \mathrm{AM}$, and this flow rate reduced up to 34 to $27 \mathrm{~m}^{3} / \mathrm{hr}$ and again this value started increasing up to 32 to $37 \mathrm{~m}^{3} / \mathrm{hr}$ at noon and after that a sharp decrease till 2 PM has been noticed from 18 to $13 \mathrm{~m}^{3} / \mathrm{hr}$. In general, this trend of flow rate remained almost constant in all seasons. However, the sum of total grey water discharged from the drain started from $4 \mathrm{AM}$ to $10 \mathrm{PM}$ were $864.76,749.0$, and $712.91 \mathrm{~m}^{3}$ in the monsoon, summer, and winter seasons, respectively. On an average, the grey water discharge from the drain were found to be 23.37, 20.26, and $19.27 \mathrm{~m}^{3} / \mathrm{hr}$ in the monsoon, summer, and winter seasons, respectively. The variation in water consumption and discharge of greywater-over-time series is always influenced by the effect of socioeconomic (Zhoua et al. 2000) and cultural factors. Thus, the grey water generation on an hourly basis represented a drastic variation within the individual day.

Table 1 Grey water characteristics and seasonal discharge pattern

\begin{tabular}{|c|c|c|c|c|c|}
\hline \multicolumn{3}{|c|}{ Grey water quality ${ }^{a}$ (mg/l except pH) } & \multicolumn{3}{|c|}{ Grey water organic load (kg/day) } \\
\hline Water quality parameters & Seasonal variation & Annual average & Season & Average flow rate basis & Maximum flow rate basis \\
\hline $\mathrm{pH}$ & 7.3 to 8.1 & 7.68 & Monsoon & $30.85 \pm 13.59^{b}$ & $55.3 \pm 35.28^{b}$ \\
\hline BOD & 52 to 68.5 & 58.5 & & & \\
\hline COD & 252 to 319 & 277.5 & & & \\
\hline Total solids & 646 to 802 & 713 & Winter & $24.05 \pm 12.37^{b}$ & $52.00 \pm 33.43^{b}$ \\
\hline Total suspended solids & 218 to 337 & 273.11 & & & \\
\hline Total dissolved solids & 392.0 to 495.25 & 439.89 & & & \\
\hline Total carbon & 206.2 to 221.0 & 208.4 & Summer & $33.31 \pm 15.79^{b}$ & $83.34 \pm 57.77^{b}$ \\
\hline Total nitrogen & 33.5 to 42.0 & 38.26 & & & \\
\hline Total phosphorus & 7.9 to 8.72 & 8.31 & & & \\
\hline Total potassium & 3.5 to 3.85 & 3.6 & Annual & $29.44 \pm 4.80^{\mathrm{b}}$ & $62.71 \pm 17.22^{b}$ \\
\hline
\end{tabular}

${ }^{\mathrm{a}}$ All values represent mean of triplicates. Standard deviations are given as \pm the mean. ${ }^{\mathrm{b}}$ Represents ANOVA ( $f$-test) significance at $0.1 \%$. Critical difference (CD) value for daily and seasonal variation recorded to be 1.86 and 6.55 , respectively. 


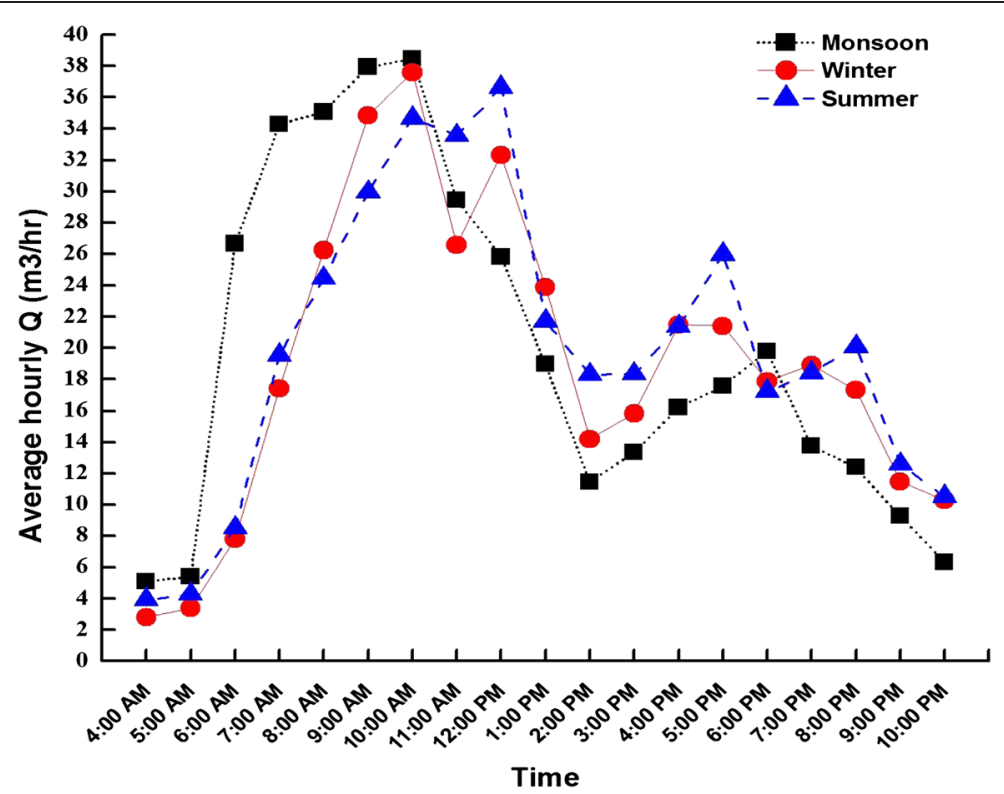

Figure 1 Hourly average flow rate $\left(\mathrm{m}^{3} / \mathrm{hr}\right)$ of grey water in different seasons.

This variation may be due to household activity varying from time to time in a day such as bathing, cloth washing, and utensil cleaning, etc.

The day-wise grey water discharge rate has been depicted in Figure 2. The figure revealed that the grey water flow rate was found maximum on Sunday, i.e., $36.12,36.10$, and $38.12 \mathrm{~m}^{3} / \mathrm{hr}$ in the monsoon, winter, and summer seasons, respectively. Whereas, the minimum grey water discharge was recorded to be on Monday during winter season and Thursday during monsoon and summer seasons, i.e., $11.75,16.55$, and $13.13 \mathrm{~m}^{3} / \mathrm{hr}$, respectively. This depicts the fluctuation in flow rate of grey water discharge in all days of the week, which in a nutshell can be best described as the overall variation of wastewater discharge, flow rate, and composition.

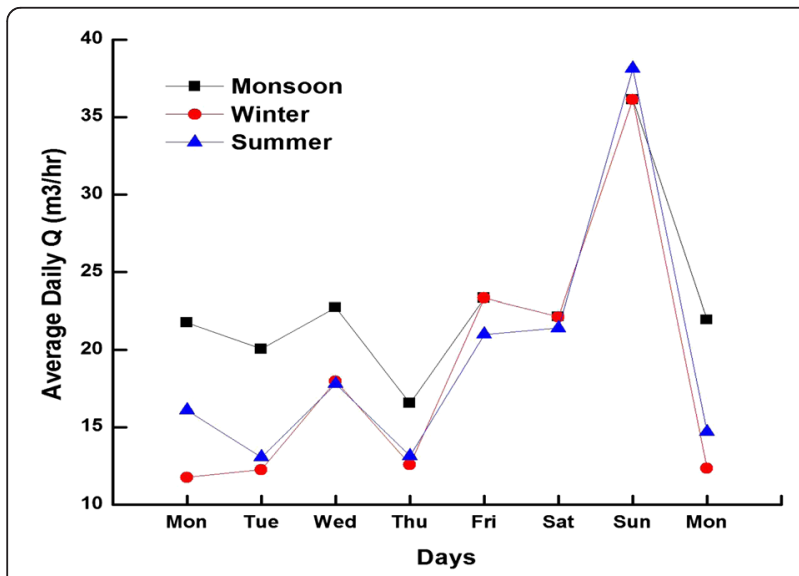

Figure 2 A season-wise portrayal of grey water 8-day average daily flow rate $\left(\mathrm{m}^{3} / \mathrm{hr}\right)$.
Besides this trend due to natural processes, properties of grey water vary at different spatial and temporal scales ( $\mathrm{Li}$ and Zhang 2007). The organic loads of grey water were calculated at average and maximum flow rate on an hourly basis and are depicted in Figure 3 . The result obtained revealed that the maximum observed value of organic loading for maximum hourly flow rate at 12 noon in monsoon and winter seasons are 136.99 and $129.03 \mathrm{~kg} /$ day, respectively. However, in the summer season, the maximum organic load was calculated for maximum flow rate in the summer season to be $216.14 \mathrm{~kg} /$ day at $11 \mathrm{AM}$. The maximum value of organic loading for average hourly flow rate was found at $10 \mathrm{AM}$ in the monsoon and winter seasons to be 50.77 and $45.85 \mathrm{~kg} /$ day, respectively. However, in the summer season, the maximum organic load was calculated at average flow rate $60.25 \mathrm{~kg} /$ day at 12 noon.

The daily organic loads pertaining to the drain system due to the magnitudes of grey water flow rate at maximum and average low rate basis and their difference is depicted in Figure 4. The result obtained from the figure revealed that the maximum observed value of organic loads at maximum and average flow on Sunday was 171.19 and $51.65 \mathrm{~kg} /$ day, respectively. However, the minimum organic load, i.e., 51.95 and $19.78 \mathrm{~kg} /$ day, was calculated at maximum and average flow rate basis on Tuesday and Thursday, respectively. The day-wise difference in organic pollutant load calculated at annual maximum and average daily flow rate was found to be $93 \%$ to $231 \%$ higher than the organic load due to annual average flow rate. Thus, it is required that the wastewater treatment system should be able to treat a wide range of pollutant loadings. 


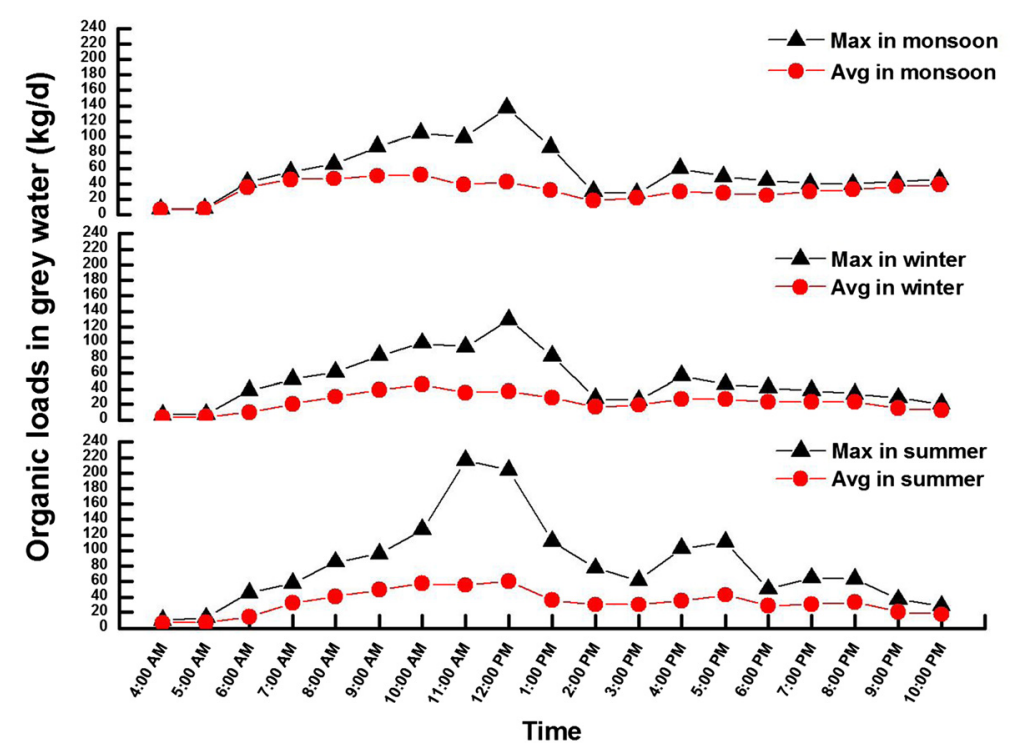

Figure 3 Seasonal trends of grey water organic loadings at average and maximum hourly flow rate basis (kg/day).

The pollutant loads pertaining to the drain system due to the magnitudes of grey water flow rate at maximum and average low rate basis and its difference varied time to time. The result negotiates that annual pollutant loads in terms of BOD, COD, N, P, K, TS, TDS, SS, and TC also change with the magnitudes of grey water. The variation pattern depicts fluctuation in pollutant loads pertaining to the treatment facility.

The fertigation trial of this grey water in Eucalyptus hybrid (clone K-413) revealed higher above-ground biomass $(A G B M)$ production per tree. The data obtained from the grey water fertigation trial was found to be $34.19 \mathrm{~kg} /$ tree in treatment plots as compared to $25.69 \mathrm{~kg} /$

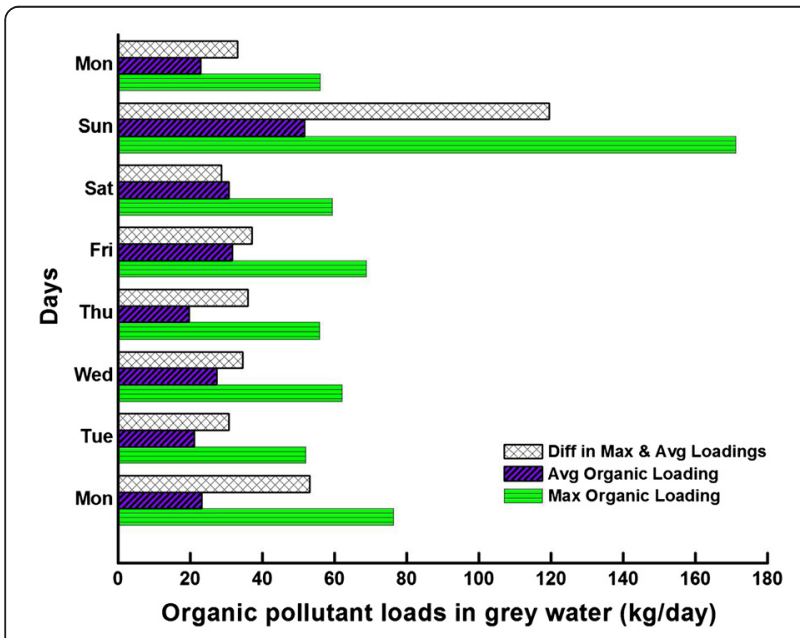

Figure 4 Magnitudes of grey water organic pollutant loads pertaining to maximum, average daily flow rate and its differences (kg/day). tree in control plots. This field observation envisages higher economic returns by fertigation due to higher biomass production per unit area as compared to control irrigation with ground water (Shankhwar and Srivastava 2014). This higher economic return was obtained in the initial 2 years of the experiment which is promising at a greater rate; in the upcoming year, more and more biomass accumulation would take place by already well-established plantations/trees. Moreover, the phytoremediation-based green technology is a solar-driven system; hence, it required a higher rate of water in the summer season due to transpiration loss which reveals the higher potential of grey water remediation in summer season.

\section{Test of significance}

Interpretation of grey water data recorded on hourly and seasonal basis were analyzed statistically using ANOVA to determine the variation at $0.05,0.01$, and 0.001 levels of significance and $f$-calculated values were found to be 16.45 and 10.55 , respectively. $P$ values for grey water data recorded on hourly and seasonal basis were calculated about 1.58 and 3.12, respectively; however, critical difference values were found about 1.86 and 6.55, respectively. In a nutshell, a significant variation among hourly and seasonal basis of grey water generation was recorded (Table 1).

\section{Conclusions}

The results concluded that the pollutant loading explicitly varied along with the magnitude of grey water. The pollutant load was found maximum in the summer season. The bioefficacy of phytoremediation-based SRICPS is also found to be at its maximum value in the summer 
season. SRICPS is socially accepted, economically viable, and even provides economic returns with higher grey water recycling potential. SRICPS-based eco-friendly green treatment system is compatible with fluctuating pollutant loads of grey water. Hence, it is found to be the best-suited green technology for mitigating the grey water pollutant loads. The long-term study about the mechanism of tree against various pollutants at different concentrations still needs to be explored.

\section{Comperting interests}

The authors declare that they have no competing interest.

\section{Authors' contributions}

Study conception, design and critical revision were done by AKS and RKS. Acquisition of data from field and help during the drafting the manuscript was done by SR. However, help during the data analysis was done by TM. All authors read and approved the final manuscript.

\section{Acknowledgement}

This research was conducted in the framework of the RCUK-DST India Science Bridge, Bioenregy: Technology and Business Solutions for the UK and India, and authors extend special thanks to Dr. P.K. Sen, Department of Applied Mechanics, IIT Delhi; Dr. Padma Vasudevan, Retd. Professor, Centre for Rural Development and Technology, IT Delhi, India; and Dr. Philip Davies, Aston University, Birmingham, UK for their technical support. The senior author of the manuscript extends their thankfulness to the University Grant Commission, Government of India, for providing financial support during the $\mathrm{PhD}$ research work.

Received: 17 July 2014 Accepted: 7 November 2014

Published online: 20 January 2015

\section{References}

APHA. (1998). Standard methods for the examination of water and wastewater (20th ed.). Washington, D.C.: American Public Health Associations/American Water Works Associations/Water Pollution Control Federation.

Bring, A, \& Destouni, G. (2011). Relevance of hydro-climatic change projection and monitoring for assessment of water cycle changes in the Arctic. Ambio, 40, 361-369.

Destouni, G, Jaramillo, F, \& Prieto, C. (2013). Hydroclimatic shifts driven by human water use for food and energy production. Nat Clim Chang, 3, 213-217.

Environmental Protection Agency. (1997). Waste Water Treatment Manuals: Primary, Secondary and Tertiary Treatment, (p. 131 p). Ireland, EPA, EPA Headquarters, Johnstown Castle Estate, County Wexford.

Henze, M, Harremoes, P, Jansen, JLC, \& Arvin, E. (2000). Wastewater treatment: biological and chemical process (3rd ed., p. 430p). New York, Springer-Verlag Berlin Heidelberg.

Jeet, I, Pandey, PC, Singh, GD, \& Shankhwar, AK. (2014). Influence of organic and inorganic sources of nutrients on growth and yield of rice in Tarai region of Uttarakhand. Ann Agric Res New Ser, 35(2), 176-182.

Koutsouris, AJ, Destouni, G, Jarsjö, J, \& Lyon, SW. (2010). Hydro-climatic trends and water resource management implications based on multi-scale data for the Lake Victoria region. Kenya Environ Res Lett, 5, 034005.

Li, Z, \& Zhang, YK. (2007). Quantifying fractal dynamics of groundwater systems with detrended fluctuation analysis. J Hydrol, 336, 139-146.

NPDES. (1977). Compliance Sampling Manual (US Environmental Protection Agency).

Pandey, A, Srivastava, RK, \& Singh, PK. (2014). Short-term impacts of gray water irrigation on soil characteristics in land-treatment vegetation filters. Commun Soil Sci Plant Anal, 45, 1305-1315.

Piao, SL, Ciais, P, Huang, Y, Shen, Z, Peng, S, Li, J, Zhou, L, Liu, H, Ma, Y, Ding, Y, Friedlingstein, P, Liu, C, Tan, K, Yu, Y, Zhang, Y, \& Fang, J. (2010). The impacts of climate change on water resources and agriculture in China. Nature, $467,43-51$.
Robert, NE. (1986). V-notch weir calibration using new parameters. J Hydraulic Engi ASCE, 112(4), 321

Shankhwar, AK, \& Srivastava, RK. (2012). Grey water: climate change mitigation. In proceedings of Third International Agronomy Congress: Agriculture Diversification, Climate Change Management and Livelihoods, jointly organized by Indian Society of Agronomy, and Indian Council of Agricultural Research (Nol. 2, pp. 360-361). New Delhi, India.

Shankhwar, AK, \& Srivastava, RK. (2014). Biomass production through grey water fertigation in Eucalyptus hybrid and its economic significance. In Environ. Prog. Sustainable Energy, John Wiley \& Sons. American Institute of Chemical Engineering. USA. doi:10.1002/ep.11968. http://onlinelibrary.wiley.com/doi/ 10.1002/ep.11968.

Wagener, T, Sivapala, M, Troch, PA, McGlynn, BL, Harman, CJ, Gupta, HV, Kumar, P, Rao, PSC, Basu, NB, \& Wilson, JS. (2010). The future of hydrology: an evolving science for a changing world. Water Resour Res, 46, W05301.

Zhoua, SL, McMahon, TA, Walton, A, \& Lewis, J. (2000). Forecasting daily urban water demand: a case study of Melbourne. J Hydrol, 236, 153-164.

\section{Submit your manuscript to a SpringerOpen ${ }^{\odot}$ journal and benefit from:}

- Convenient online submission

Rigorous peer review

- Immediate publication on acceptance

- Open access: articles freely available online

- High visibility within the field

- Retaining the copyright to your article

Submit your next manuscript at $\gg$ springeropen.com 